\title{
HAZCI VE FAYDACI YAKLAŞIMIN MARKA BAĞI OLUŞUMUNDAKİ ROLÜ*
}

\author{
THE ROLE OF HEDONIST AND UTILITARIAN APPROACH ON THE \\ FORMATION OF BRAND ATTACHMENT
}

\section{Nurhan BABÜR TOSUN ${ }^{* *}$ Mevlüt DÖNMEZ ${ }^{* *}$}

\section{Öz}

Ürün ve hizmetler arasındaki fonksiyonel farkların ortadan kalkmasıyla, markalar rekabette ayrışabilmek ve tüketici zihninde uzun süreli bir yer elde edebilme çabasına girmişlerdir. Bu noktada, tüketicilerle uzun süreli bir etkileşime önem veren işletmeler, tüketicilerde bir marka bağı oluşturma gayreti içerisindedirler. Yaşamları boyunca çeşitli markaları satın alan tüketiciler ise sınırlı markalarla aralarında uzun süreli bağlar geliştirmektedirler. İşletmeler, tüketicilerle aralarında güçlü ve sürekli bir marka bağı oluşturmak için reklam çalışmalarından faydalanmaktadır. Reklamlarda kullanılan hazcı ve faydacı mesajların marka bağı oluşturma etkisinden faydalanan işletmeler, oluşturdukları reklam içerikleriyle tüketicilerle markalar arasında uzun süreli bağ kurma çabasına girmektedirler. Bu çalışma kapsamında, reklamlarda kullanılan hazcı, faydacı ve her iki mesaj türünü içeren hem hazcı hem de faydacı mesajların tüketicilerde oluşan marka bağına yönelik rolü incelenmektedir. Araştırmada her bir reklam türünün belirlenen tanımlayıcı özellikler (yaş, cinsiyet, eğitim düzeyi, medeni durum, aktif olarak çalışma durumu, aylık gelir düzeyi ve daha önce IKEA mağazasını ziyaret etme durumu) açısından marka bağı oluşturmadaki rolü irdelenmiştir. IKEA reklamları üzerine gerçekleştirilen araştırma sonucunda, bağ oluşumunda en yoğun etkiyi reklamlardaki hem hazcı hem de faydacı

* $\quad$ Makale Gönderim Tarihi: 20.03.2018; Kabul Tarihi: 26.03.2018.

Bu çalışma TUBİTAK 2211-Yurt İçi Doktora Burs Programı tarafından desteklenmiştir.

** Marmara Üniversitesi, İletişim Fakültesi, Halkla İlişkiler ve Tanıtım Bölümü, Prof. Dr., ORCID ID: 0000-0003-0234-9647

*** Süleyman Demirel Üniversitesi, İletişim Fakültesi, Halkla İlişkiler ve Tanıtım Bölümü, Arş. Gör, ORCID ID: 0000-0002-8437-7416 
mesajların birlikte kullanımının yaptığı görülürken, ikinci sırada hazcı mesajlar yer almakta ve bağın oluşumunda üç mesaj tipi arasında en düşük etkiye sahip mesaj tipinin faydacı reklam mesajlarının olduğu görülmüştür.

Anahtar Kelimeler: Marka, Marka Bağı, Reklam, Hazcı Reklamlar, Faydacı Reklamlar

JEL Sınıflaması: M30, M31, M37

\section{Abstract}

Functional differences between products and services have begun to disappear and this has seriously affected the market shares of brands and the competition conditions. In addition to this, today's consumers are seen as individuals whose loyalty is weak and purchasing decisions are rapidly changing. It is thought that consumers will only be interested in the brands they feel close to, and they will use their purchasing preferences for these brands. At this point, it is assumed that consumers who buy and use many brands throughout their lifetime will develop strong ties with a limited number of brands. It is seen that consumers who develop an attachment to a brand tend to use that brand at all costs and they are faced with a negative feeling in the absence of brand. These individuals become fans of this brand and advocate the brand both on the internet and in real life. In such a case, consumers also show considerable resistance to the brand's competitors. Individuals who have a sense of attachment to a brand spend their time and money, energy, etc., even if they have limited resources, to buy and use that brand. Moreover, consumers tend to ignore this when they have problems with the brands they are attached to. In summary, consumers who feel attached to any brand are thought to be loyal consumers who tend to buy that brand constantly. Therefore, brands have started to focus on the elements that will connect brands and consumers in order to be able to stand out from the competition, to get a long-term place in consumer mind, and to provide customer value. Brands build their all marketing components on establishing a strong attachment basis between consumers and brand. In this sense, the factors affecting brand attachment are mainly classified as compatibility with the individual, experience, ability to respond to consumer needs, brand reputation, trust, and quality. Advertising is another factor that helps businesses connect with consumers. Brands aim to establish attachment with consumers through advertising messages. At this point, the hedonist and utilitarian contents used in advertising helps brands connect with their consumers. Joy, fun, pleasure elements are generally used in hedonist advertisements. The advertisements focus on the pleasure elements consumers will obtain after using the product or service. In these advertisements, consumers are drawn into a fantasy world. The individuals who watch the advertisement experience excitement. In order to keep this experience alive, emotional appeal is utilized in advertisements. Thus, consumers feel good and have positive emotions. Another type of advertisement is the utilitarian advertisments. Informative ads usually show reasonable reasons for purchasing a promoted product. These advertisements highlight the product features and focus on the real, functional attributes that the consumer will acquire. In this type of advertising, the target audience is informed about the possession of the product, reasons for using the product and its requirements by a logical approach. This information contains factual, logical and objectively provable expressions. In summary, these advertisements emphasize the product's attributes and its concrete benefits. In this context, the quality of the product, price value and performance are shown in utilitarian advertising contents. Utilitarian advertisings are aimed at convincing consumers 
that the characteristics and advantages of the advertised product or service are better than the competitors because of their informative nature. Utilitarian advertisings use rational advertising appeals for this purpose. In summary, businesses struggle to establish attachment between consumers and brands, through the use of hedonist and utilitarian advertising messages in advertisements. This study examines the role of hedonist, utilitarian and the advertisings including message types, hedonist and utilitarian, on the brand attachment established in consumers. In addition, the role of each message type in establishing brand attachment has also been examined in terms of identified descriptive attributes (age, gender, education level, marital status, active working status, monthly income level and previous visit to IKEA store). The research was conducted on IKEA ads. In the study, causal research method was used as a research type and convenience sampling method was used as a sampling type. In this context, an online survey was conducted on 502 men and women whose ages are between 18 and 35 constituted the target group of IKEA. At the end of the research, it is seen that the most intense effect to establish attachment has been created by the use of both hedonist and utilitarian messages in advertisements together. The second most intense effect has been created by hedonist messages and it is seen that the type of the message with the lowest effect among the three message types in the formation of attachment is the utilitarian advertising messages. In addition, it is concluded that each advertising type differs relatively compared to the descriptive attributes in terms of creating attachment.

Keywords: Brand, Brand Attachment, Advertisement, Hedonistic Advertising, Utility Advertising

JEL Classification: M30, M31, M37

\section{I.GíRiş}

Pazar yapılarındaki rekabetin gün geçtikçe zorlaşması, markaların fonksiyonel niteliklerle birbirlerinden farklılaşmalarının artık neredeyse imkânsız hale gelmesiyle birlikte işletmeler kendilerini rekabetten farklılaştıracak yeni yöntemler arayışına girmişlerdir. Bu noktada uzun süreli bir ilişki temeli kurma ve sadık müşteriler elde etme markaların birincil hedefleri arasında yer almaktadır. Böyle bir amaç çerçevesinde, pazarlama ve iletişim yöntemlerinden faydalanan markalar, son yıllarda tüketicilerle markalar arasında sürekli bir yakınlığ 1 temsil eden marka bağı kavramına önem vermektedir. Psikoloji çerçevesinden baktığımızda bağ, kişiler ile canlı veya cansız nesneler arasında gerçekleşen duygusal bağlantı olarak görülmektedir (Mahmood vd., 2015: 839). Buradan yola çıkarak, bireyler ile markalar arasındaki bağın, duygusal temelli olduğu görülmekte ve herhangi bir markaya bağlı olan tüketiciler için ilgili marka pek çok anlamı beraberinde taşımaktadır. Bu duygusal bağ öylesine güçlüdür ki, tüketicilerin markaya ulaşamaması durumunda bireyin duygusal anlamda bir kayıp hissine kapılacağı düşünülmektedir (Schifferstein ve Zwartkruis-Pelgrim, 2008: 1). Bu doğrultuda, bireylerin aralarında bağ kurdukları markalara yönelik bir satın alma isteği-

nin olacağı öngörülmektedir (Jawahar ve Maheswari, 2009: 10). Ürün ve hizmetlerin satın alıcısı konumunda olan tüketicilerin etkileşime girdiği ürün sayısı oldukça fazladır. Ancak 
tüm bu etkileşim sayısının fazlalığına rağmen bireyler sınırlı sayıda bir markayla aralarında bağ kurma eğilimindedir (Thomson vd., 2005: 77). Bu bağın gücü bazı durumlarda o kadar yoğun olmaktadır ki, tüketiciler o markayı satın almak için tüm kaynaklarını zorlamaktadırlar. Bu noktada, bireylerin markalara yönelik bağ kurma yapısını anlamak ve buna yönelik strateji geliştirmek, işletmeler için önemli bir konudur (Cheong, 2013: 263). Bu önemin temelinde uzun süreli bir müşteri sadakati ve satın alma sürekliliği unsurları yatmaktadır. Herhangi bir markaya yönelik güçlü bağlar geliştiren tüketiciler, markalar açısından bir satın alma garantisi sunarken, rakip işletmelerin tüketici zihnini karıştırma ihtimalini de minimum seviyeye düşürmektedir (Park, 2016: 4). Tüketicileriyle bağ kurmak isteyen işletmeler çeşitli pazarlama ve iletişim uygulamalarına başvurmaktadır. Bu uygulamalardan biri ise reklamdır. İsletmeler reklamlarda kullandıkları mesajlar aracılığıyla tüketici ile marka arasında bir bağ kurma çabasına girmektedirler. Bu noktada hazcı ve faydacı reklam mesajlarının, markaların amaçlarına hizmet ettiği görülmektedir. Tüketimin iki boyutu olan hazcı ve faydacı yaklaşım (Babin vd., 1994: 645) bu noktada önem kazanmaktadır. Gerçekleştirilen tüketimin, fonksiyonel faydalar, pratiklik, ekonomik anlamda kâr amaçlı yapılması faydacı tüketim çerçevesinde düşünülebileceği gibi; satın almanın keyif ve duygusal tatmin amaçlı yapılması ise hazcı tüketim çerçevesinde düşünülmektedir (Ahmed, 2015: 76). Bireylerin tüketim amaçlarını dikkate alan reklam mesajları yoluyla oluşturulan reklam içeriklerinin marka bağı oluşturmaya aracılık ettiği düşünülmekte, aracıllğın yoğunluğunun kullanılan mesajın niteliğine göre değişebileceği varsayılmaktadır. Bu çalışmada hazcı, faydacı ve her iki mesaj türünün birlikte kullanıldığı hem hazcı hem de faydacı reklam mesajlarının marka bağı oluşturmaya yönelik rolünün incelenmesi amaçlanmıştır.

\section{II.KURAMSAL ÇERÇEVE}

\section{1. Marka Bağı Kavramı ve Önemi}

Ürünler ve markalar arasındaki benzerliklerin gün geçtikçe artması, işletmeleri rakiplerinden farklılaşacak yöntemler aramaya yönlendirmektedir. Markaların rakiplerinden farklılaşma amacıyla hedef kitleleriyle uzun süreli ilişki kurduğu yöntemlerden biri de, tüketici ile marka arasında bir bağ oluşturmaktadır. Bireyler bir çok ürünü satın almanın yanında, belirli markalarla aralarında güçlü bağlar kurabilmektedir (Thomson vd., 2005: 77). Tüketicilerle markalar arasındaki bağı açıklayan bir terim olan marka bağı (Japutra vd., 2014: 618) en kısa şekliyle "bir markaya yönelik sevgi, tutku ve bağlantı gibi olumlu hislere sahip olmak" biçiminde tanımlanabilir (Chen ve Xu, 2015: 1421). Schmalz ve Orth (2012: 872) ise marka bağı kavramını "tüketicilerin bir markaya yönelik duygusal hislerinin derecesi ve markanın kendilerini ifade etme ve tanımlama dereceleri” șeklinde tanımlamaktadır.

Marka bağı kavramı temelde, çocukluğun erken döneminde, bireyin kendisiyle ilgilenen bireylerle etkileşimlerinin daha sonraki yaşamında ilişkilerini şekillendireceğini öne süren 
bağ kuramına (Bowbly 1969, 1980; Ainsworth ve Bowlby, 1991) dayanmaktadır (Cheong, 2013: 263; Swaminathan vd., 2009: 985;). Tüketicilerle marka arasında güçlü bir bağın oluşması, bireylerin markayı deneyimlemesi sonucunda, zaman içerisinde gerçekleşmekte ve derinleşmektedir (Huang vd., 2017: 1199). Bu bağlamda bir markaya yönelik bağı olan müşterilerin, alternatif markalara yönelmesinin daha zor olacağı düşünülmektedir. Bunun yanında, bağ kurulan markanın, kullanıcının uzantısı olarak görüldüğü varsayılmaktadır (Park, 2016: 4). Marka bağının psikolojik yapısı incelendiğinde, buradaki temel faktörün tüketicilerin cansız nesnelere insani özellikler atfetmesi olduğu görülmektedir. Kısacası, bireyler, markaları bir arkadaş, dost hatta aile gibi görmekte, onları birer insan olarak zihninde kodlamaktadır ve bunun sonucunda tüketicilerle marka arasında bir bağ oluşmaktadır (Huaman-Ramirez, 2015: 161). Marka bağını duygusal temelde değerlendiren yaklaşıma göre, markaya yönelik tüketicilerde ortaya çıkan duygular ve hisler, bireylerle marka arasında bir düşünce, ilişki ve sevgi ağı kurmaktadır (Thomson vd., 2005'den aktaran Mahmood vd., 2015: 839). Bu bağlamda marka bağına etki eden faktörlerin, bağın niteliğinde ve derinliğinde önemli bir rolü olduğu varsayılmaktadır. Marka bağının oluşumunda etkisi olan faktörleri; benlik uyumu, deneyim, tüketici ihtiyaçlarına cevap verebilme yeteneği, marka itibarı, güven, kalite (Park vd. 2010; Japutra vd., 2014) şeklinde sıralayabilmek mümkündür.

Tüketicilerle marka arasında güçlü bir ilişkiyi temsil eden marka bağı sayesinde, bireyler bağ kurdukları markaları her ne pahasına olursa olsun satın almaya koşullanmaktadır. Ayrıca bu tüketiciler markalar hakkında olumlu söylemler gerçekleştirmekte ve işletmenin pazar paylarına olumlu katkı yapmaktadır (Cheong, 2013: 263). Bunun yanında tüketicilerin, markaya yönelik ilgi ve bağı olan diğer bireylerle arasında güçlü bir sosyal ağ kuracağ1 varsayılmaktadır (Fournier, 2009). Böylece, bireylerin markaları kullanarak hem kendilerini ifade edebileceği hem de oluşan sosyal ağ sayesinde olumlu duygulara sahip olacağı öngörülmektedir (Allison vd., 2016: 3). Bununla beraber, bireylerin markaya yönelik bağlarını korumak ve bu bağ 1 güçlendirmek için markaya daha fazla sadakat göstereceği düşünülmektedir. Bu açıdan bakıldığında, güçlü bir marka bağına sahip bireyler, diğer markaların mesajlarına karşı da ciddi bir direnç göstereceği ve bağ kurduğu markaya yönelik para, zaman ve enerji bakımından daha fazla çaba sarf edeceği beklenmektedir (Huang vd., 2017: 1199). Özetle, marka ile tüketiciler arasındaki güçlü bir bağın, mevcut (Esch vd., 2006) ve gelecekteki satın alma isteği, fazla ödeme yapmaya yönelik eğilimi (Fedorikin vd., 2008) başta olmak üzere pek çok sonuç üzerinde olumlu yönde bir katkısı olduğu varsayılmaktadır (Gillespie ve Noble, 2017: 230). Tüm bunlara ek olarak, herhangi bir marka ile arasında güçlü bir bağa sahip olan tüketicilerin, markanın sunduğu faydayla ilgili herhangi bir sorunla karşılaştıklarında bu durumu dahi affetme ve markayı yine de savunma isteğinde oldukları düşünülmektedir (Schmalz ve Orth, 2012). Tüm bu yorumlamalardan yola çlkarak, bireylerle markalar arasındaki ilişkinin gücünü açıklayan marka bağının; kârlılığın ve uzun süreli müşteri 
değerini artıran davranışları etkilemesi yönünde ciddi bir öneme sahip olduğunu söylemek doğru olacaktır (Park vd. 2010: 1).

\section{II.2. Hazcı - Faydacı Tüketim ve Reklam İlişkisi}

Genel bir çerçeveden bakıldığında, bireylerin tüketim değerlerinin hazcı ve faydacı olarak iki boyutta gerçekleştiğini söylemek mümkündür (Hirschman ve Holbrook, 1982). Ürün ya da hizmetlerin fonksiyonel faydasına odaklanan faydacı değerin yanında, alışverişi bir deneyim süreci olarak gören hazcı tüketim ise bu deneyim sonucunda elde edeceği haz ve keyif durumlarına odaklanmaktadır (Babin vd., 1994: 645). Ürün veya hizmet açısından baktığımızda, hazcı isteklerle satın alınan ürünlerin özellikle öznel ve soyut niteliklere sahip olması beklenmektedir. Bu bağlamda, pırlanta, parfüm, çikolata, film, tatil ve mobilya gibi deneyime dayalı, eğlence ve duyguları açığa çıkaran ürünlerin hazcı ürün kategorisi içerisinde değerlendirildiği görülmektedir (Baek ve Choo, 2015; Chopra, 2014; Khan vd., 2005; Lu vd., 2016). Bu doğrultuda temel ihtiyaçlara yönelik olan salata, kırtasiye malzemesi, ofis mobilyası, yazıcı, kitap, yapıştırma amaçlı kullanılan ürünler, hesap makinesi, cam ve plastik eşyalar, alkalin pil, deterjan, diş macunu ve tedavi amaçlı ürünler faydacı ürün kategorisi arasında sayılabilmektedir (Hirschman ve Holbrook, 1982; O'curry ve Strahilevitz, 2001; Voss vd., 2003)

Deneyimi merkez alan hazcı yaklaşım bağlamında oluşturulan reklamlar, tüketicilerin duygularını harekete geçirmeyi amaçlamakta, onların zihinlerinde işletmeye yönelik anlamlar ve imajlar oluşturmaktadır (Uztuğ, 2008: 200). Duygusal ve psikolojik beklentilere odaklanan hazcı reklamlarda, satın alma faaliyeti tanıtımı yapılan ürünün kullanılmasıyla elde edilecek ödül ya da kullanılmaması durumunda maruz kalınacak kötü durumlar üzerinde durmaktadır (Elden ve Bakır, 2010: 89). Duygu temelli hazcı reklamların aksine ürünlerin fonksiyonel faydalarına odaklanan faydacı reklamlar ise ürünlerin satın alınmasına yönelik mantıksal nedenler sunmaktadır. Faydacı temelde oluşturulan reklam içeriklerinde ürünlerin özellikleri vurgulanarak, tüketicilerin elde edecekleri işlevsel değerler gösterilmektedir. Özetle, bu reklam tarzında ürünün performansı, kalitesi, fonksiyonel avantajları üzerinde durulmaktadır (Jovanović vd., 2016: 37).

Tüketicilerle marka arasında bağın oluşmasında duygular büyük önem taşımaktadır (Odabaşı ve Barış, 2007: 183). Böyle bir bilinç doğrultusunda hareket eden reklam ve pazarlama uygulayıcıları, markalara yönelik bir bağ oluşturmak için duygulardan yararlanmaktadır. Olası bir bağ durumunda tüketici, markayı kendisinin bir uzantısı olarak görecek böylece oluşan bu bağ tüketici sadakatini de beraberinde getirecektir (Thakur ve Kaur, 2016: 71-73). Marka bağına duygu temelli bir çerçeveden yaklaşan Thomson ve diğerleri (2005) de marka bağını; sevgi, tutku ve bağlantı öğeleriyle karakterize etmektedir. Heath ve diğerleri (2006), tüketicilerle marka arasında oluşacak duygusal bağa aracılık eden reklamların, derin 
ve güçlü bağlar oluşturma amacı taşıyorsa reklam içeriklerindeki duygu yoğunluğunun arttırılması gerektiğini ifade etmektedir (Aktaran Mahmood vd., 2015: 839)

Hazcı tüketim bağlamında tüketicilerin satın alma kararı vermesinde duygusal etmenler etkili olurken, faydacı tüketim bağlamında ise bireylerin ürün ve hizmetlere yönelik kararlarını vermelerinde kalite, güvenilirlik ve ürünün performans başarısı etkili olmaktadır (Erciş vd., 2011: 24). Ürün ve hizmetlerin bu anlamdaki başarısının markaya yönelik tutumu pozitif yönde etkilediği ve satın alma kararına yönlendirdiği varsayılmaktadır. Özetle, tüketiciler ile markaları arasında güçlü bağlar kurmak isteyen firmaların ürün veya hizmetlerinin işlevsel başarısını yansıtan performans, kalite ve güvenilirlik unsurlarına ağırlık vermeleri gerektiği söylenebilir.

\section{ARAŞTIRMA}

Tüketiciler ile markalar arasındaki bağın oluşmasında etkin olan faktörlerden birisi reklam olarak gösterilmektedir. Reklam mesajları yoluyla, bireyler ile markalar arasında bağ oluşturmak amaçlanmaktadır (Elden ve Bakır, 2010: 215). Bu bağlamda, reklam mesajlarında kullanılan hazcı ve faydacı mesajların tüketiciler ile marka arasında uzun süreli bir bağ yapısına aracılık edeceği düşünülmektedir. Bu bağlamda çalışmanın amacı hazcı, faydacı ve hem hazcı hem faydacı reklamların tüketicide oluşan marka bağında hangisinin daha etkin role sahip olduğunu incelemektir. Bunun yanında araştırmada; her bir reklam türünün yaş, cinsiyet, eğitim düzeyi, medeni durum, aktif olarak çalı̧̧ma durumu, aylık gelir düzeyi ve daha önce IKEA mağazasını ziyaret etme durumu şeklinde belirlenen tanımlayıcı özelliklere göre marka bağı oluşumundaki rolü incelenmiştir. Çalışma kapsamında ele alınacak ürün kategorisinin reklam mesajlarına uygun olarak hem hazcı hem de faydacı ürün niteliklerini taşıması amaçlanmıştır. Bu bağlamda hem hazcı hem de faydacı kriterler doğrultusunda satın alınan (Burnsed, 2009; Chopra, 2014; Gijsberg, 2014) mobilya ürünü araştırma dâhilinde ele alınmıştır. Araştırmada incelenecek olan markanın, reklamlarında hem hazcı hem de faydacı mesajların ayrı ayrı ve bir arada kullanılması önem taşımaktadır. Bu doğrultuda, IKEA markası incelenecek olan mesaj tiplerini reklamlarında kullanması ve satın alma kriterlerinde hem hazcı hem de faydacı olarak değerlendirilmesi (Pachaki, 2013: 9) açısından araştırmada kullanılmasına karar verilmiştir. Çalışma kapsamında IKEA reklamlarından faydacı reklam örneği için "IKEA Yatak Odası Reklamı" (YouTube, 2015) tercih edilmiştir. Hazcı reklam örneği için "IKEA Tost Reklamı” (YouTube, 2018) tercih edilirken, hem hazcı hem de faydacı reklam örneği için ise "IKEA Oturma Odası Reklamı" (YouTube, 2016) tercih edilmiştir. Bu reklamların seçilmesinin sebebi araştırma kapsamında belirlenen reklam mesajlarına uygun olmasıdır.

Pazarlama araştırmalarında, neden sonuç ilişkisini inceleyen araştırma türü nedensel araştırma olarak tanımlanmaktadır (Gegez, 2015: 48). Çalışma kapsamında nedensel 
araştırma türü kullanılmıştır. IKEA markasının hedef kitlesi 18 - 35 yaş arası (Combe, 2014: 548) bireylerden meydana geldiği için araştırma ilgili yaş aralığındaki kadın ve erkek tüketiciler üzerinde gerçekleştirilmiştir. Pazarlama araştırmalarında 'problem çözümüne yönelik yapılan araştırmalar' da tipik örnek hacminin 300 ile 500 arasında olması gerekmektedir (Naresh ve Birks, 2000: 351). Araştırmada, ulaşılabilir bireylerin araştırma kapsamında değerlendirildiği örneklem türü olan kolayda örneklemden (Gegez, 2015: 266) faydalanılarak, 500 kişilik bir örneklem miktarına ulaşılmak hedeflenmiştir. IKEA markasının Türkiye'de İstanbul (2), Ankara, Bursa ve İzmir illerinde mağazası bulunmaktadır. Ancak markanın internet üzerinden satı̧̧ hizmeti vermesi araştırmaya farklı şehirleri dâhil edebilme imkânı sunmaktadır. Ancak yine de araştırma sonuçlarının tüm Türkiye’ye genellemesi gibi bir durum söz konusu değildir. Marka bağına yönelik gerçekleştirilen önceki çalışmalardan (Alex ve Joseph, 2012; Azizağaoğlu ve Atunışık, 2011; Büyük vd., 2014; Can, 2016; Deniz ve Erciş, 2010; Erciş vd., 2011; Lehto, 2013; Thomson vd., 2005) hareketle bu araştırmanın sorgulayacağı hipotezler ise aşağıdaki gibi belirlenmiştir:

H1: Marka bağı hazcı, faydacı, hem hazcı hem faydacı reklam türüne göre anlamlı farklılık göstermektedir.

H2: Faydacı reklam türüne ilişkin marka bağı, tanımlayıcı özelliklere göre anlamlı farklılık göstermektedir.

H3: Hazcı reklam türüne ilişkin marka bağı, tanımlayıcı özelliklere göre anlamlı farklılık göstermektedir.

H4: Hem hazcı hem faydacı reklam türüne ilişkin marka bağı, tanımlayıcı özelliklere göre anlamlı farklılık göstermektedir.

\section{III.1. Analiz ve Yorumlar}

Araştırmada veri toplama aracı olarak anket seçilmiştir. Anket çevrimiçi yöntemle uygulanmıştır. Araştırmaya toplamda 542 kişi katılmış ancak 40 anketin geçersiz olmasından dolayı araştırma 502 kişi üzerinden değerlendirilmiştir. Anket kişisel bilgi formu ve üç reklam türüne ilişkin marka bağını belirlemeye yönelik ölçekten oluşmaktadır. Kişisel bilgi formunda; yaş, cinsiyet, eğitim düzeyi, medeni durum, aktif olarak çalışma durumu, aylık gelir düzeyi, daha önce IKEA mağazası ziyaret etme durumu değişkenlerine yer verilmiștir.

Anket formunun oluşturulmasında Thomson vd. (2005) tarafından yapılan, geliştirilen ölçekten faydalanılmıştır. Bu bağlamda 10 maddelik bir anket formu tasarlanmıştır. Katılımcılara izledikleri reklamlara ilişkin marka bağını belirlemek üzere sevecen, arkadaş canlısı (arkadaşça), sevgi hissettiren, huzur veren, tutku hissettiren, keyif ve mutluluk veren, cezbeden ve büyüleyen, bağ hissettiren, yakınlık hissettiren, aileden olduğunu hissettiren sıfatlarına ilişkin görüş belirtmeleri istenmektedir. İfadeler (1) "Hiç" ile (7) “Tamamen" arasında yanttlanmaktadır. 
Ölçeğin güvenirlik ve geçerliğini belirlemek üzere Cronbach Alpha ve açılayıcı faktör analizi yapılmıştır. Yapılan Barlett Testi sonucunda $(\mathrm{p}=0.000<0.05)$ faktör analizine alınan değişkenler arasında ilişkinin olduğu tespit edilmiştir. Yapılan test sonucunda $(\mathrm{KMO}=0.956>0,60)$ örnek büyüklüğünün faktör analizi uygulanması için yeterli olduğu tespit edilmiştir. Faktörler arasındaki ilişkinin aynı kalmasını sağlamak açısından, faktör analizinde Varimax yöntemi tercih edilmiştir. Faktör analizi sonucunda değişkenler toplam açıklanan varyansı \%93.107 olan 3 faktör (sevgi, tutku ve bağlantı) altında toplanmıştır. Güvenirliğine ilişkin bulunan Alpha ve açıklanan varyans değerine göre marka bağı ölçeğinin geçerli ve güvenilir bir araç olduğu belirlenmiştir. Ölçeğe ait oluşan faktör yapısı aşağıda görülmektedir.

Tablo 1: Marka Bağı Ölçeği Faktör Yapısı

\begin{tabular}{|c|c|c|c|c|}
\hline Boyut & Madde & Faktör Yükü & $\begin{array}{l}\text { Açılkanan } \\
\text { Varyans }\end{array}$ & $\begin{array}{l}\text { Cronbach's } \\
\text { Alpha }\end{array}$ \\
\hline \multirow{4}{*}{$\begin{array}{l}\text { Sevgi } \\
\text { (Özdeğer=8.742) }\end{array}$} & Sevecen & 0,774 & \multirow{4}{*}{32,654} & \multirow{4}{*}{0,969} \\
\hline & Arkadaş Canlısı (arkadaşça) & 0,728 & & \\
\hline & Sevgi Hissettiren & 0,692 & & \\
\hline & Huzur Veren & 0,633 & & \\
\hline \multirow{3}{*}{$\begin{array}{l}\text { Tutku } \\
\text { (Özdeğer=0.291) }\end{array}$} & Cezbeden ve Büyüleyen & 0,783 & \multirow{3}{*}{30,851} & \multirow{3}{*}{0,952} \\
\hline & Tutku Hissettiren & 0,731 & & \\
\hline & Keyif ve Mutluluk Veren & 0,645 & & \\
\hline \multirow{3}{*}{$\begin{array}{l}\text { Bağlantı } \\
\text { (Özdeğer=0.278) }\end{array}$} & Aileden Olduğunu Hissettiren & 0,745 & \multirow{3}{*}{29,602} & \multirow{3}{*}{0,975} \\
\hline & Yakınlık Hissettiren & 0,736 & & \\
\hline & Bağ Hissettiren & 0,729 & & \\
\hline
\end{tabular}

Ölçekteki faktörlerin puanları hesaplanırken, faktördeki maddelerin değerleri toplandıktan sonra madde sayısına bölünerek (aritmetik ortalama) faktör puanları elde edilmiştir. Ölçekten ve alt boyutlardan alınan puanlar 1 ile 7 arasında değişmektedir. Ölçekten alınan puanın yükselmesi marka bağının arttığını göstermektedir.

Araştırmada elde edilen veriler SPSS (Statistical Package for Social Sciences) for Windows 22.0 programı kullanılarak analiz edilmiştir. Verilerin değerlendirilmesinde tanımlayıcı istatistiksel yöntemleri olarak sayı, yüzde, ortalama, standart sapma kullanılmıştır. Reklam türlerine göre marka bağları arasındaki fark tekrarlı ölçüm ANOVA (Repeated Measures Anova) testi ile analiz edilmiştir. İki bağımsız grup arasında niceliksel sürekli verilerin karşılaştırılmasında t-testi, ikiden fazla bağımsız grup arasında niceliksel sürekli verilerin karşılaştırılmasında tek yönlü (One way) anova testi kullanılmıştır. ANOVA testi sonrasında farklılıkları belirlemek üzere tamamlayıcı post-hoc analizi olarak Scheffe Testi kullanılmıştır. 
Tablo 2: Reklam Türlerine Göre Marka Bağı Puanları

\begin{tabular}{|c|c|c|c|c|c|c|c|}
\hline Ölçümler & $\mathrm{N}$ & Ort & Ss & $\mathrm{F}$ & p & $\eta^{2}$ & Fark \\
\hline Faydacı reklam marka bağı genel & 502 & 3,429 & 1,769 & \multirow[t]{3}{*}{100,882} & \multirow[t]{3}{*}{0,000} & \multirow[t]{3}{*}{0,168} & \multirow{3}{*}{$\begin{array}{l}3>1,2 \\
2>1\end{array}$} \\
\hline Hazcı reklam marka bağı genel & 502 & 3,816 & 1,896 & & & & \\
\hline Hem faydacı hem de hazcı reklam marka bağı genel & 502 & 4,127 & 1,926 & & & & \\
\hline
\end{tabular}

Marka bağı genel boyutu, farklı reklam türlerine göre anlamlı farklılık göstermektedir $(\mathrm{F}=100,882 ; \mathrm{p}=0,000<0,05)$. Üç farklı reklam türüne ilişkin etki büyüklüğü toplam varyansın \%16,8'ini açıklamaktadır $(\eta 2=0,168)$. Farklılıkları belirlemek üzere Posthoc Bonferroni analizi yapılmıştır. Hem faydacı hem de hazcı reklama ilişkin marka bağı düzeyi, faydacı reklam ve hazcı reklam marka bağı düzeyinden yüksek bulunmuştur. Hazcı reklam marka bağı düzeyi faydacı reklam marka bağı düzeyinden yüksektir. Bu doğrultuda araştırma kapsamında oluşturulan 'H1' hipotezinin kabul olduğu varsayılmaktadır. Bu bağlamda reklamda hazcı ve faydacı mesajların birlikte kullanımının marka bağı oluşturmak adına diğer mesaj tiplerine göre daha fazla katkı sağlayacağı düşünülmektedir.

Tablo 3: Faydacı Reklama İlişkin Marka Bağının Tanımlayıcı Özelliklere Göre Karşılaştırılması

\begin{tabular}{|c|c|c|c|c|c|}
\hline Demografik Özellikler & $\mathbf{n}$ & $\begin{array}{l}\text { Faydacı Reklam } \\
\text { Sevgi }\end{array}$ & $\begin{array}{l}\text { Faydacı Reklam } \\
\text { Tutku }\end{array}$ & $\begin{array}{l}\text { Faydacı Reklam } \\
\text { Bağlantı }\end{array}$ & $\begin{array}{l}\text { Faydacı Reklam } \\
\text { Marka Bağı Genel }\end{array}$ \\
\hline Yaş & & Ort \pm SS & Ort \pm SS & Ort \pm SS & Ort $\pm S S$ \\
\hline $18-25$ yaş & 189 & $3,454 \pm 1,777$ & $3,365 \pm 1,800$ & $3,480 \pm 1,977$ & $3,435 \pm 1,765$ \\
\hline 26-30 yaş & 165 & $3,450 \pm 1,747$ & $3,277 \pm 1,735$ & $3,394 \pm 1,959$ & $3,381 \pm 1,745$ \\
\hline 31-35 yaş & 148 & $3,525 \pm 1,750$ & $3,363 \pm 1,824$ & $3,516 \pm 2,059$ & $3,474 \pm 1,811$ \\
\hline $\mathrm{F}=$ & & 0,091 & 0,132 & 0,157 & 0,108 \\
\hline $\mathrm{p}=$ & & 0,913 & 0,876 & 0,855 & 0,898 \\
\hline Cinsiyet & & Ort \pm SS & Ort $\pm S S$ & Ort \pm SS & Ort \pm SS \\
\hline Kadın & 294 & $3,470 \pm 1,756$ & $3,315 \pm 1,775$ & $3,527 \pm 2,042$ & $3,441 \pm 1,784$ \\
\hline Erkek & 208 & $3,478 \pm 1,760$ & $3,364 \pm 1,797$ & $3,370 \pm 1,921$ & $3,412 \pm 1,752$ \\
\hline$t=$ & & $-0,051$ & $-0,301$ & 0,870 & 0,182 \\
\hline$p=$ & & 0,959 & 0,764 & 0,385 & 0,855 \\
\hline Eğitim Düzeyi & & Ort \pm SS & Ort $\pm S S$ & Ort \pm SS & Ort $\pm S S$ \\
\hline Lise ve altı & 85 & $4,227 \pm 1,779$ & $4,220 \pm 1,810$ & $4,251 \pm 2,004$ & $4,232 \pm 1,789$ \\
\hline Önlisans & 70 & $3,943 \pm 1,643$ & $3,833 \pm 1,598$ & $4,110 \pm 1,916$ & $3,960 \pm 1,622$ \\
\hline Lisans & 220 & $3,158 \pm 1,654$ & $3,029 \pm 1,723$ & $3,138 \pm 1,894$ & $3,113 \pm 1,678$ \\
\hline Lisansüstü & 127 & $3,258 \pm 1,786$ & $3,000 \pm 1,718$ & $3,139 \pm 1,979$ & $3,145 \pm 1,768$ \\
\hline $\mathrm{F}=$ & & 10,444 & 13,379 & 10,528 & 12,122 \\
\hline$p=$ & & 0,000 & 0,000 & 0,000 & 0,000 \\
\hline PostHoc= & & $\begin{array}{l}1>3,2>3,1>4,2>4 \\
(\mathrm{p}<0.05)\end{array}$ & $\begin{array}{l}1>3,2>3,1>4,2>4 \\
(\mathrm{p}<0.05)\end{array}$ & $\begin{array}{l}1>3,2>3,1>4,2>4 \\
(\mathrm{p}<0.05)\end{array}$ & $\begin{array}{l}1>3,2>3,1>4,2>4 \\
(\mathrm{p}<0.05)\end{array}$ \\
\hline
\end{tabular}




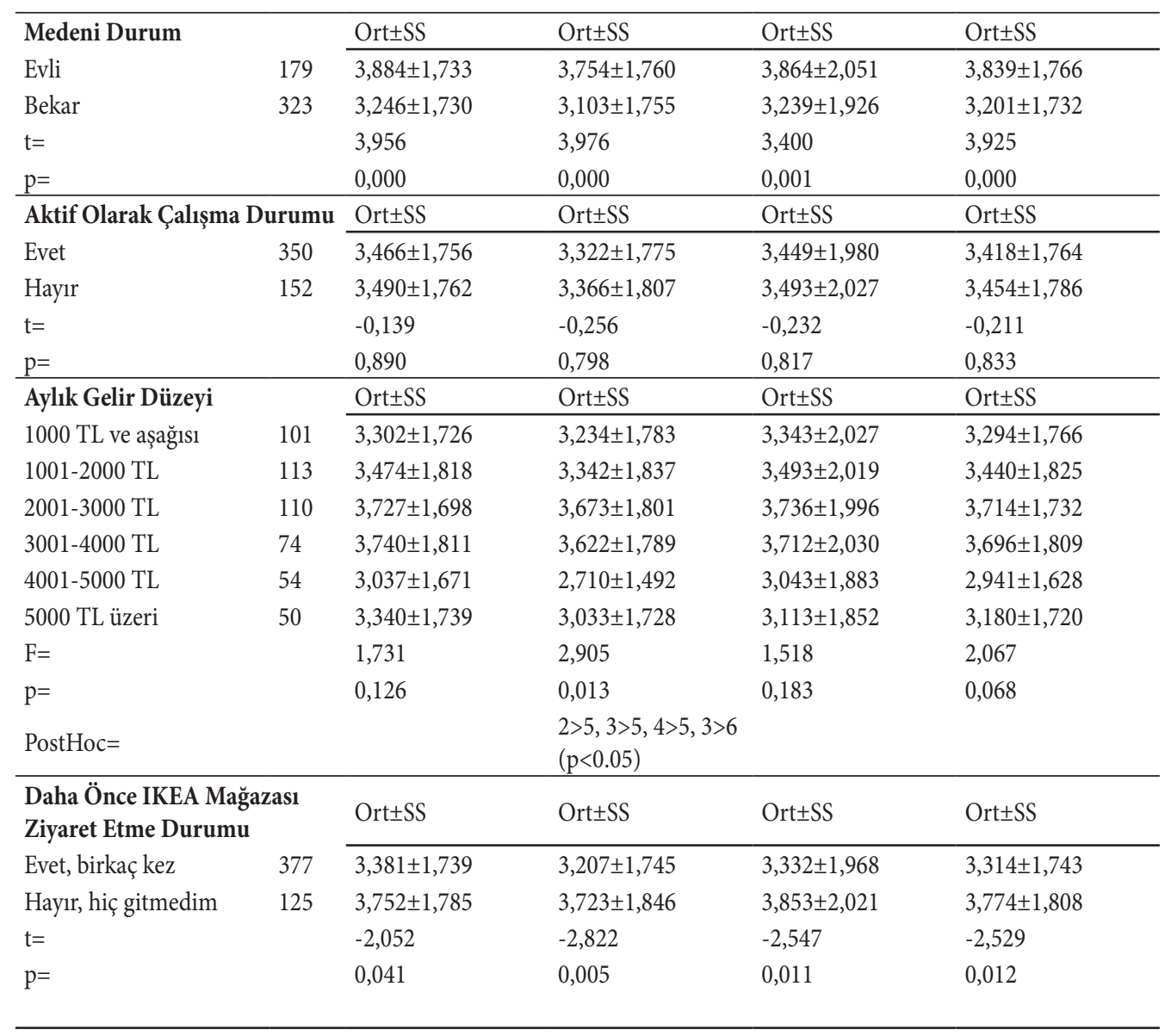

Elde edilen bulgular doğrultusunda, faydacı reklamların marka bağı oluşturmasında eğitim durumu, medeni durum ve IKEA mağazasını ziyaret etme durumuna göre anlamlı farklılıkların ortaya çıktığı görülmektedir $(\mathrm{F}=12,122 ; \mathrm{p}=0<0.05)$. Bu doğrultuda, eğitim seviyesi önlisans ve daha düşük olan bireylerin, eğitim seviyesi lisans ve üstü olan bireylere göre daha yoğun bir marka bağına sahip oldukları varsayılmaktadır. Bir diğer tanımlayıcı değişken olan medeni durum açısından bakıldığında ise evli tüketicilerin $(x=3,839)$ bekâr tüketicilere $(x=3,201)$ göre daha yoğun bir marka bağına sahip oldukları görülmektedir. IKEA mağazasını ziyaret etme durumu açısından bakıldığında, IKEA mağazasına daha önce gitmemiş bireylerin $(x=3,774)$ giden tüketicilere $(x=3,314)$ göre daha yüksek bir marka bağı oranına sahip olduğu verisine ulaşılmıştır $(\mathrm{t}=-2,529 ; \mathrm{p}=0.012<0.05)$. Araştırma kapsamında belirlenen aylık gelir durumu, yaş, cinsiyet ve aktif olarak çalışma durumu açısından bakıldığında ise, bu değişkenler ile marka bağı arasında anlamlı bir farklılığın olmadığı sonucuna erişilmiştir ( $p>0.05$ ). Elde edilen bulgular doğrultusunda 'H2' hipotezinin kısmen kabul edildiği varsayılmaktadır. 
Tablo 4: Hazcı Reklama İlişkin Marka Bağının Tanımlayıcı Özelliklere Göre Karşılaştırılması

\begin{tabular}{|c|c|c|c|c|c|}
\hline Demografik Özellikler & $\mathbf{n}$ & $\begin{array}{l}\text { Hazcı Reklam } \\
\text { Sevgi }\end{array}$ & $\begin{array}{l}\text { Hazcı Reklam } \\
\text { Tutku }\end{array}$ & $\begin{array}{l}\text { Hazcı Reklam } \\
\text { Bağlantı }\end{array}$ & $\begin{array}{l}\text { Hazcı Reklam } \\
\text { Marka Bağı } \\
\text { Genel }\end{array}$ \\
\hline Yaş & & Ort $\pm S S$ & Ort \pm SS & Ort $\pm S S$ & Ort \pm SS \\
\hline $18-25$ yaş & 189 & $3,918 \pm 1,926$ & $3,755 \pm 1,915$ & $4,067 \pm 2,140$ & $3,914 \pm 1,932$ \\
\hline $26-30$ yaş & 165 & $3,727 \pm 1,866$ & $3,578 \pm 1,762$ & $3,913 \pm 2,059$ & $3,738 \pm 1,838$ \\
\hline $31-35$ yaş & 148 & $3,843 \pm 1,925$ & $3,563 \pm 1,850$ & $3,910 \pm 2,174$ & $3,779 \pm 1,920$ \\
\hline $\mathrm{F}=$ & & 0,444 & 0,588 & 0,315 & 0,417 \\
\hline $\mathrm{p}=$ & & 0,642 & 0,556 & 0,730 & 0,659 \\
\hline Cinsiyet & & Ort $\pm S S$ & Ort $\pm S S$ & Ort \pm SS & Ort $\pm S S$ \\
\hline Kadın & 294 & $3,846 \pm 1,953$ & $3,617 \pm 1,854$ & $4,006 \pm 2,167$ & $3,825 \pm 1,932$ \\
\hline Erkek & 208 & $3,815 \pm 1,837$ & $3,673 \pm 1,836$ & $3,920 \pm 2,059$ & $3,804 \pm 1,848$ \\
\hline$t=$ & & 0,181 & $-0,336$ & 0,446 & 0,124 \\
\hline $\mathrm{p}=$ & & 0,855 & 0,737 & 0,656 & 0,901 \\
\hline Eğitim Düzeyi & & Ort \pm SS & $\mathrm{Ort} \pm \mathrm{SS}$ & Ort \pm SS & Ort \pm SS \\
\hline Lise ve altı & 85 & $4,809 \pm 1,722$ & $4,624 \pm 1,660$ & $4,843 \pm 2,019$ & $4,764 \pm 1,719$ \\
\hline Ön lisans & 70 & $4,443 \pm 1,807$ & $4,229 \pm 1,654$ & $4,662 \pm 2,019$ & $4,444 \pm 1,759$ \\
\hline Lisans & 220 & $3,497 \pm 1,910$ & $3,341 \pm 1,887$ & $3,641 \pm 2,155$ & $3,493 \pm 1,927$ \\
\hline Lisansüstü & 127 & $3,427 \pm 1,759$ & $3,176 \pm 1,671$ & $3,575 \pm 1,934$ & $3,396 \pm 1,729$ \\
\hline $\mathrm{F}=$ & & 15,247 & 16,423 & 11,157 & 15,007 \\
\hline $\mathrm{p}=$ & & 0,000 & 0,000 & 0,000 & 0,000 \\
\hline PostHoc $=$ & & $\begin{array}{l}1>3,2>3,1>4 \\
2>4(\mathrm{p}<0.05)\end{array}$ & $\begin{array}{l}1>3,2>3,1>4 \\
2>4(\mathrm{p}<0.05)\end{array}$ & $\begin{array}{l}1>3,2>3,1>4 \\
2>4(p<0.05)\end{array}$ & $\begin{array}{l}1>3,2>3,1>4, \\
2>4(p<0.05)\end{array}$ \\
\hline Medeni Durum & & Ort \pm SS & Ort $\pm S S$ & Ort \pm SS & Ort $\pm S S$ \\
\hline Evli & 179 & $4,183 \pm 1,909$ & $4,026 \pm 1,788$ & $4,419 \pm 2,090$ & $4,207 \pm 1,861$ \\
\hline Bekar & 323 & $3,639 \pm 1,876$ & $3,426 \pm 1,844$ & $3,721 \pm 2,101$ & $3,600 \pm 1,883$ \\
\hline$t=$ & & 3,090 & 3,529 & 3,571 & 3,472 \\
\hline $\mathrm{p}=$ & & 0,002 & 0,000 & 0,000 & 0,001 \\
\hline Aktif Olarak Çalışma Durumu & & Ort \pm SS & Ort \pm SS & Ort \pm SS & Ort \pm SS \\
\hline Evet & 350 & $3,844 \pm 1,858$ & $3,623 \pm 1,815$ & $4,002 \pm 2,120$ & $3,825 \pm 1,865$ \\
\hline Hayır & 152 & $3,809 \pm 2,012$ & $3,680 \pm 1,917$ & $3,897 \pm 2,129$ & $3,797 \pm 1,970$ \\
\hline$t=$ & & 0,186 & $-0,318$ & 0,509 & 0,153 \\
\hline $\mathrm{p}=$ & & 0,857 & 0,751 & 0,611 & 0,879 \\
\hline Aylık Gelir Düzeyi & & Ort \pm SS & Ort \pm SS & Ort \pm SS & Ort \pm SS \\
\hline 1000 TL ve aşağısi & 101 & $3,644 \pm 1,976$ & $3,522 \pm 1,928$ & $3,746 \pm 2,140$ & $3,638 \pm 1,960$ \\
\hline $1001-2000 \mathrm{TL}$ & 113 & $3,894 \pm 1,960$ & $3,693 \pm 1,867$ & $4,018 \pm 2,170$ & $3,871 \pm 1,948$ \\
\hline $2001-3000 \mathrm{TL}$ & 110 & $4,182 \pm 1,858$ & $3,997 \pm 1,855$ & $4,382 \pm 2,097$ & $4,186 \pm 1,870$ \\
\hline $3001-4000 \mathrm{TL}$ & 74 & $3,960 \pm 1,924$ & $3,860 \pm 1,875$ & $4,203 \pm 2,217$ & $4,003 \pm 1,936$ \\
\hline $4001-5000 \mathrm{TL}$ & 54 & $3,278 \pm 1,645$ & $2,957 \pm 1,513$ & $3,451 \pm 1,985$ & $3,233 \pm 1,642$ \\
\hline 5000 TL üzeri & 50 & $3,725 \pm 1,861$ & $3,387 \pm 1,705$ & $3,627 \pm 1,882$ & $3,594 \pm 1,759$ \\
\hline $\mathrm{F}=$ & & 1,997 & 2,859 & 2,179 & 2,370 \\
\hline $\mathrm{p}=$ & & 0,078 & 0,015 & 0,055 & 0,038 \\
\hline PostHoc $=$ & & & $\begin{array}{l}2>5,3>5,4>5 \\
(p<0.05)\end{array}$ & & $\begin{array}{l}3>1,2>5,3>5 \\
4>5(p<0.05)\end{array}$ \\
\hline
\end{tabular}




\begin{tabular}{|c|c|c|c|c|}
\hline $\begin{array}{l}\text { Daha Önce IKEA Mağazası Ziyaret Etme } \\
\text { Durumu }\end{array}$ & Ort $\pm S S$ & Ort $\pm S S$ & Ort $\pm S S$ & Ort $\pm S S$ \\
\hline Evet, birkaç kez $\quad 377$ & $3,681 \pm 1,847$ & $3,505 \pm 1,821$ & $3,832 \pm 2,085$ & $3,674 \pm 1,850$ \\
\hline Hayır, hiç gitmedim & $4,292 \pm 2,006$ & $4,048 \pm 1,865$ & $4,387 \pm 2,183$ & $4,247 \pm 1,973$ \\
\hline $\mathrm{t}=$ & $-3,136$ & $-2,873$ & $-2,547$ & $-2,955$ \\
\hline $\mathrm{p}=$ & 0,002 & 0,004 & 0,011 & 0,003 \\
\hline
\end{tabular}

Elde edilen bulgular doğrultusunda, hazcı reklamların marka bağı oluşturmasında eğitim durumu, aylık gelir, medeni durum ve IKEA mağazasını ziyaret etme durumuna göre anlamlı farklılıkların ortaya çıtı̆̆ı görülmektedir. Sonuçlara bakıldığında, eğitim seviyesi ön lisans ve daha düşük olan bireylerin, lisans ve üstü olan bireylere göre daha yoğun bir marka bağına sahip oldukları varsayılmaktadır. Bir diğer tanımlayıcı özellik olan aylık gelir durumu açısından baktığımızda, en yüksek marka bağına sahip olan bireylerin 2001-3000 TL arasındaki gelire sahip olan bireyler olduğu görülmektedir. Medeni durum açısından bakıldığında ise, evli tüketicilerin $(x=4,207)$ bekâr tüketicilere $(x=3,600)$ göre daha yoğun bir marka bağına sahip oldukları görülmektedir. IKEA mağazasını ziyaret etme değişkeni açısından bakıldığında, IKEA mağazasına daha önce gitmemiş bireylerin $(x=4,292)$ giden tüketicilere $(x=3,681)$ göre daha yüksek bir marka bağ tır. Araştırma kapsamında belirlenen yaş, cinsiyet ve aktif olarak çalışma durumu açısından bakıldığında ise, bu değişkenler ile marka bağı arasında anlamlı bir farklılığın olmadığı sonucuna erişilmiştir ( $p>0.05$ ). Elde edilen bulgular doğrultusunda 'H3' hipotezinin kısmen kabul edildiği varsayılmaktadır.

Tablo 5: Hem Faydacı Hem Hazcı Reklama İlişkin Marka Bağının Tanımlayıcı Özelliklere Göre Karşılaştırılması

\begin{tabular}{|c|c|c|c|c|c|}
\hline $\begin{array}{l}\text { Demografik } \\
\text { Özellikler }\end{array}$ & $\mathbf{n}$ & $\begin{array}{l}\text { Hem Faydacı Hem } \\
\text { De Hazcı Reklam } \\
\text { Sevgi }\end{array}$ & $\begin{array}{l}\text { Hem Faydacı Hem } \\
\text { De Hazcı Reklam } \\
\text { Tutku }\end{array}$ & $\begin{array}{l}\text { Hem Faydacı Hem } \\
\text { De Hazcı Reklam } \\
\text { Bağlantı }\end{array}$ & $\begin{array}{l}\text { Hem Faydacı Hem } \\
\text { De Hazcı Reklam } \\
\text { Marka Bağı Genel }\end{array}$ \\
\hline Yaş & & Ort $\pm S S$ & Ort $\pm S S$ & Ort \pm SS & Ort \pm SS \\
\hline $18-25$ yaş & 189 & $4,318 \pm 2,023$ & $4,111 \pm 1,946$ & $4,150 \pm 1,984$ & $4,205 \pm 1,931$ \\
\hline $26-30$ yaş & 165 & $4,191 \pm 1,890$ & $3,921 \pm 1,836$ & $4,139 \pm 1,922$ & $4,095 \pm 1,831$ \\
\hline $31-35$ yaş & 148 & $4,260 \pm 2,123$ & $3,851 \pm 1,999$ & $4,009 \pm 2,066$ & $4,062 \pm 2,031$ \\
\hline $\mathrm{F}=$ & & 0,175 & 0,840 & 0,245 & 0,263 \\
\hline $\mathrm{p}=$ & & 0,840 & 0,432 & 0,783 & 0,769 \\
\hline Cinsiyet & & Ort \pm SS & Ort \pm SS & Ort \pm SS & Ort \pm SS \\
\hline Kadın & 294 & $4,356 \pm 2,022$ & $4,006 \pm 1,933$ & $4,164 \pm 1,970$ & $4,194 \pm 1,929$ \\
\hline Erkek & 208 & $4,121 \pm 1,983$ & $3,925 \pm 1,920$ & $4,021 \pm 2,010$ & $4,032 \pm 1,923$ \\
\hline$t=$ & & 1,292 & 0,464 & 0,798 & 0,924 \\
\hline $\mathrm{p}=$ & & 0,197 & 0,643 & 0,425 & 0,356 \\
\hline Eğitim Düzeyi & & Ort \pm SS & Ort \pm SS & Ort \pm SS & Ort \pm SS \\
\hline Lise ve alt1 & 85 & $4,918 \pm 2,010$ & $4,698 \pm 1,845$ & $4,565 \pm 1,945$ & $4,746 \pm 1,887$ \\
\hline Önlisans & 70 & $4,864 \pm 1,976$ & $4,543 \pm 1,753$ & $4,619 \pm 1,806$ & $4,694 \pm 1,807$ \\
\hline
\end{tabular}




\begin{tabular}{|c|c|c|c|c|c|}
\hline Lisans & 220 & $3,996 \pm 1,962$ & $3,714 \pm 1,945$ & $3,929 \pm 2,078$ & $3,891 \pm 1,938$ \\
\hline Lisansüstü & 127 & $3,941 \pm 1,944$ & $3,619 \pm 1,856$ & $3,819 \pm 1,853$ & $3,808 \pm 1,851$ \\
\hline $\mathrm{F}=$ & & 7,805 & 9,251 & 4,638 & 7,492 \\
\hline $\mathrm{p}=$ & & 0,000 & 0,000 & 0,003 & 0,000 \\
\hline PostHoc $=$ & & $\begin{array}{l}1>3,2>3,1>4,2>4 \\
(\mathrm{p}<0.05)\end{array}$ & $\begin{array}{l}1>3,2>3,1>4,2>4 \\
(\mathrm{p}<0.05)\end{array}$ & $\begin{array}{l}1>3,2>3,1>4,2>4 \\
(\mathrm{p}<0.05)\end{array}$ & $\begin{array}{l}1>3,2>3,1>4,2>4 \\
(\mathrm{p}<0.05)\end{array}$ \\
\hline Medeni Durum & & Ort $\pm S S$ & Ort $\pm S S$ & Ort $\pm S S$ & Ort \pm SS \\
\hline Evli & 179 & $4,643 \pm 2,006$ & $4,292 \pm 1,900$ & $4,423 \pm 1,974$ & $4,472 \pm 1,913$ \\
\hline Bekar & 323 & $4,046 \pm 1,979$ & $3,795 \pm 1,920$ & $3,929 \pm 1,973$ & $3,936 \pm 1,910$ \\
\hline$t=$ & & 3,216 & 2,792 & 2,686 & 3,010 \\
\hline $\mathrm{p}=$ & & 0,001 & 0,005 & 0,007 & 0,003 \\
\hline $\begin{array}{l}\text { Aktif Olarak Çalışm } \\
\text { Durumu }\end{array}$ & & Ort $\pm S S$ & Ort $\pm S S$ & Ort $\pm S S$ & Ort $\pm S S$ \\
\hline Evet & 350 & $4,256 \pm 1,996$ & $3,941 \pm 1,912$ & $4,101 \pm 1,985$ & $4,115 \pm 1,917$ \\
\hline Hayır & 152 & $4,265 \pm 2,039$ & $4,044 \pm 1,962$ & $4,114 \pm 1,993$ & $4,153 \pm 1,955$ \\
\hline$t=$ & & $-0,043$ & $-0,550$ & $-0,068$ & $-0,204$ \\
\hline $\mathrm{p}=$ & & 0,966 & 0,583 & 0,946 & 0,839 \\
\hline Aylık Gelir Düzeyi & & Ort $\pm S S$ & Ort $\pm S S$ & Ort \pm SS & Ort $\pm S S$ \\
\hline 1000 TL ve aşağısı & 101 & $4,134 \pm 1,983$ & $3,861 \pm 1,903$ & $3,997 \pm 1,965$ & $4,011 \pm 1,903$ \\
\hline $1001-2000 \mathrm{TL}$ & 113 & $4,292 \pm 2,040$ & $4,021 \pm 1,925$ & $4,059 \pm 1,975$ & $4,141 \pm 1,937$ \\
\hline $2001-3000 \mathrm{TL}$ & 110 & $4,546 \pm 1,983$ & $4,349 \pm 1,880$ & $4,464 \pm 1,933$ & $4,462 \pm 1,884$ \\
\hline $3001-4000 \mathrm{TL}$ & 74 & $4,389 \pm 2,048$ & $4,090 \pm 1,929$ & $4,320 \pm 2,146$ & $4,278 \pm 1,990$ \\
\hline $4001-5000 \mathrm{TL}$ & 54 & $3,861 \pm 2,093$ & $3,438 \pm 1,970$ & $3,667 \pm 1,944$ & $3,676 \pm 1,979$ \\
\hline 5000 TL üzeri & 50 & $4,045 \pm 1,862$ & $3,660 \pm 1,916$ & $3,793 \pm 1,888$ & $3,854 \pm 1,824$ \\
\hline $\mathrm{F}=$ & & 1,134 & 2,092 & 1,749 & 1,634 \\
\hline $\mathrm{p}=$ & & 0,341 & 0,065 & 0,122 & 0,149 \\
\hline \multicolumn{2}{|c|}{$\begin{array}{l}\text { Daha Önce IKEA Mağazası } \\
\text { Ziyaret Etme Durumu }\end{array}$} & Ort $\pm S S$ & Ort $\pm S S$ & Ort $\pm S S$ & Ort $\pm S S$ \\
\hline Evet, birkaç kez & 377 & $4,153 \pm 1,967$ & $3,856 \pm 1,884$ & $4,023 \pm 1,960$ & $4,025 \pm 1,887$ \\
\hline Hayır, hiç gitmedim & 125 & $4,580 \pm 2,099$ & $4,323 \pm 2,015$ & $4,352 \pm 2,049$ & $4,434 \pm 2,018$ \\
\hline$t=$ & & $-2,070$ & $-2,359$ & $-1,608$ & $-2,068$ \\
\hline$p=$ & & 0,046 & 0,019 & 0,108 & 0,047 \\
\hline
\end{tabular}

Elde edilen bulgular doğrultusunda hem hazcı hem faydacı reklamların marka bağı oluşturmada eğitim durumu, medeni durum ve IKEA mağazasını ziyaret etme durumuna göre anlamlı farklılıkların ortaya çıktığı görülmektedir. Sonuçlara bakıldığında, eğitim seviyesi ön lisans ve daha düşük olan bireylerin, lisans ve üstü olan bireylere göre daha yoğun bir marka bağına sahip oldukları varsayılmaktadır. Bir diğer tanımlayıcı değişken olan medeni durum açısından bakıldığında ise, evli tüketicilerin $(x=4,472)$, bekâr tüketicilere $(x=3,936)$ göre faydacı reklamları izlediklerinde daha yoğun bir marka bağına sahip oldukları görülmektedir. IKEA mağazasını ziyaret etme değişkeni açısından bakıldığında, IKEA mağazasına daha önce gitmemiş bireylerin $(x=4,434)$ giden tüketicilere $(x=4,025)$ göre daha yüksek bir marka bağı oranına sahip olduğu verisine ulaşılmıştır. Araştırma kapsamında belirlenen gelir durumu, yaş, cinsiyet ve aktif olarak çalışma durumu açısından bakıldığında ise, 
bu değişkenler ile marka bağı arasında anlamlı bir farklılığın olmadığı sonucuna erişilmiştir ( $p>0.05$ ). Elde edilen bulgular doğrultusunda 'H4' hipotezinin kısmen kabul edildiği varsayllmaktadir.

\section{III.2. Araştırma Sonucu}

Araştırma kapsamında, hazcı, faydacı ve hem hazcı hem faydacı reklam mesajlarının hangisinin marka bağı oluşturmada daha güçlü bir etkiye sahip olduğu incelenmiştir. Bunun yanında her bir reklam türünün belirlenen tanımlayıcı özellikler çerçevesinde marka bağı oluşumundaki rolü irdelenmiştir. Yapılan analizler doğrultusunda, her üç reklam türü içerisinde marka bağı oluşturmak açısından en yoğun etkiye sahip olan reklam türünün hem hazcı hem de faydacı reklamlar olduğu görülmüsstür. Ek olarak, hazcı reklam türünün, faydacı reklam türüne göre marka bağı oluşturmada daha etkin olduğu sonucu elde edilmiştir. Bu doğrultuda, markaların reklam mesajlarına maruz kalan bireylerin, hem hazcı hem faydacı mesajları bir arada kullanan markaların reklamlarından daha fazla etkileneceği ve diğer mesajlarla kıyaslandığında markaya yönelik daha güçlü bir bağ geliştireceği düşünülmektedir. Bu bağlamda, marka ile tüketici arasında bağ kurmaya yönelik reklam stratejisi geliştiren işletmelerin reklamlarında hem hazcı hem faydacı mesajları bir arada kullanmasının bu amaca ulaşmalarına katkısı olacağı beklenmektedir.

Araştırma dâhilinde üç farklı reklam türünün marka bağı oluşturmadaki rolü tanımlayıcı özelliklere göre irdelenmiştir. Faydacı reklam koşulunda, marka bağı oluşumu ile eğitim durumu, medeni durum ve IKEA mağaza ziyaret etme durumu arasında farklılıkların olduğu görülürken; yaş, gelir durumu, cinsiyet ve aktif çalışma durumu açısından farklılıkların olmadığı sonucuna erişilmiştir. Bu bağlamda, faydacı reklamlar koşulunda en yüksek marka bağının ön lisans ve altı eğitim durumunda olan, evli ve IKEA mağazasını daha önce ziyaret etmeyen bireylerde gerçekleștiği görülmüştür. Hazcı reklam koşulunda ise marka bağ1 oluşumu ile eğitim durumu, aylık gelir, medeni durum ve IKEA mağazasını ziyaret etme arasında farklılıkların olduğu görülürken; yaş, cinsiyet ve aktif çalışma durumu arasında anlamlı farklılıklara erişilmemiştir. Bu doğrultuda, hazcı reklamlarla karşılaşan tüketiciler arasından marka bağını en yoğun hisseden bireyler ön lisans ve altı eğitim seviyesine sahip, evli, 2001-3000 TL arasında gelire sahip olan ve IKEA mağazasını daha önce ziyaret etmeyen bireylerdir. Hem hazcı hem faydacı reklam koşulu altında incelendiğinde, marka bağ 1 oluşumu ile eğitim durumu, medeni durum ve IKEA mağazasını ziyaret etme arasında anlamlı farklılıklar görünürken; yaş, cinsiyet, aylık gelir ve aktif çalışma durumu arasında farklılıklara rastlanmamıștır. Bu bağlamda, hem hazcı hem faydacı reklam koşulunda en yüksek marka bağı puanına sahip bireyler ön lisans ve altı eğitim seviyesine sahip, evli ve daha önce IKEA mağazasını ziyaret etmeyen bireyler olduğu görülmektedir. Genel olarak bakıldığında, marka bağı oluşturmak açısından en etkili reklamın hem hazcı hem de faydacı mesajları birlikte barındıran reklamlar olduğu görülmektedir. Bunun yanında eğitim seviyesi ön lisans ve 
altı olan, evli ve IKEA mağazasını daha önce ziyaret etmemiş bireyler reklamlarla karşılaştıklarında, diğer bireylere göre, reklam mesajlarından daha fazla etkilenebileceği ve markaya yönelik bağ oluşturabileceği düşünülmektedir.

\section{SONUÇ VE ÖNERILER}

Her markanın birincil hedefleri arasında yer alan tüketiciler ile işletme arasında sürekli bir iletişimin en önemli sağlayıcılarından biri marka bağıdır. Tüketici ile marka arasında gerçekleşen deneyimle oluşan ve gelişen marka bağının bireylerin bağ geliştirdikleri markaya yönelik satın almaya daha istekli olduğu bir duruma zemin hazırladığı görülmektedir. Bağ geliştirdikleri markaları satın alma tercihlerinde ön sıraya alan tüketiciler bunun yanında rakip markalara yönelik de satın alma direnci göstermektedir (Huang vd., 2017: 1199). Markaların iletişim stratejilerine temel oluşturan marka bağı kavramının oluşmasına aracılık eden unsurlardan biri de reklamlardır. Reklamlar kullandıkları hazcı ve faydacı mesaj içerikleriyle tüketiciler ile markalar arasında bir bağ oluşturmaya çalışmaktadır. Bu bağlamda, araştırma kapsamında hazcı, faydacı ve hem hazcı hem de faydacı reklam türünün hangisinin marka bağı oluşturmada daha güçlü bir etkiye sahip olduğu irdelenirken, her bir mesaj türünün tanımlayıcı değişikliklere göre bağa aracılık rolü incelenmiştir.

Araştırma kapsamında, marka bağı oluşturmada en güçlü etkiye sahip olan reklam türünün her iki mesaj türünü bir arada kullanan hem hazcı hem faydacı reklamlar olduğu görülmüştür. Diğer yandan hazcı reklamların faydacı reklamlara göre daha güçlü bir etkiye sahip olduğu sonucu ortaya çıkmıştır. Bu bağlamda, her iki mesaj türünün bir arada kullanıldığ1 reklamlarla karşılaşan bireylerin, tanıtımı yapılan markaya daha güçlü bir bağ hissedeceği, reklam mesajlarından daha fazla etkileneceği ve bu etkinin satın alma kararına yansıyacağ 1 ön görülmektedir. Araştırma sonucunda, faydacı reklam koşulunda, ön lisans ve altı eğitim seviyesine sahip, evli ve daha önce IKEA mağazasını ziyaret etmeyen bireylerin markalara yönelik daha güçlü bir bağa sahip olacakları düşünülmektedir. Bu bağlamda, eğitim seviyesi daha düşük olan bireylerin faydacı reklam mesajlarına daha açı olduğu görülürken, evli tüketicilerin faydacı mesajlardan etkilendiği sonucuna ulaşılmıştır. Hazcı reklam koşulunda değerlendirildiğinde, ön lisans ve altı eğitim seviyesine sahip, evli, daha önce IKEA mağazasını ziyaret etmeyen ve gelir durumu 2001-3000 TL arasında olan bireylerin markalara yönelik daha güçlü bir bağa sahip olacakları düşünülmektedir. Bu bağlamda, eğitim seviyesi daha düşük olan bireylerin haz odaklı reklam mesajlarına daha açık olduğu görülürken, evli tüketicilerin hazcı mesajlardan etkilendiği sonucuna ulaşılmıştır. Hem hazcı hem faydacı reklamlar bağlamında bakıldığında, ön lisans ve altı eğitim seviyesine sahip, evli ve daha önce IKEA mağazasını ziyaret etmeyen bireylerin markalara yönelik daha güçlü bir bağa sahip olacakları düşünülmektedir. Bu bağlamda, eğitim seviyesi daha düşük olan bireylerin hem hazcı hem faydacı reklam mesajlarına daha açık olduğu görülürken, evli tüketicilerin her iki mesaj türünden etkilendiği sonucuna ulaşılmıştır. Her üç koşulda da IKEA mağazasına 
daha önce gitmeyenlerin, gidenlerden daha yüksek bir bağa sahip olması ise marka ile tüketici arasında yaşanan deneyimden kaynaklı bir problem olacağı ihtimalini doğurmaktadır.

Üç reklam türünün marka bağı oluşturmadaki rollerinin incelendiği bu araştırmanın marka bağı literatürüne katkı yapacağı düşünülmektedir. Ayrıca çalışmanın, reklam stratejilerinin belirlenmesi temelinde sektörel anlamda da yararlı olacağı ön görülmektedir. Gerçekleştirilen çalışma tek bir ürün kategorisi ve marka üzerinden yapıldığı için araştırmanın tüm ürün grupları ve markalara genellenmesi mümkün değildir. Bu çalışmanın, marka bağ bağlamında farklı ürün grupları ve markalara uyarlanarak yapılacak daha kapsamlı araştırmalara ışı tutacağı düşünülmektedir.

\section{Yararlanılan Kaynaklar}

Ahmed, K. (2015). Utilitarian and Hedonic Motives of University Students In Their Online Shopping - A Gender Based Examination. Sona Global Management Review. 9 (4), 75-91.

Allison, L., Flahertya, K. E., Ho Junga, J. ve Washburnb, I. (2016). Salesperson Brand Attachment: A Job Demands-Resources Theory Perspective. Journal of Personal Selling and Sales Management, 36 (1), 3-18.

Babin, B. J., Darden, W. ve Griffin, R. M. (1994). Work and/or Fun: Measuring Hedonic and Utilitarian Shopping Value. Journal of Consumer Research. 30, 644-656.

Baek, Eunsoo ve Choo, Ho Jung, (2015). Effects of Peer Consumption on Hedonic Purchase Decisions. Social Behavior and Personality 43(7), 1085-1100.

Chen, R. ve Xu, X. (2015). Consistency Between Consumer Personality and Brand Personality Influences Brand Attachment. Social Behavior and Personality. 43(9), 1419-1428.

Cheong, A. L. H. (2013). An Exploration of Antecedents and Consequences of Brand Attachment among a Cross Section of Malaysian Consumers. Asian Social Science. 9(5), 263-273.

Chopra, K. (2014). Study Of Relaitonship Between Utilitarian and Hedonic Motives And Temporal Perpective At Retail Malls. International Journal For Research In Applied Science And Engineering Technology. 2 (3), 35-41.

Elden M. ve Bakır U. (2010). Reklam Çekicilikleri. İletişim Yayınları, İstanbul.

Erciş, A., Yapraklı, Ş., Can, P., ve Yılmaz, M. K. (2011). Tüketicilerin Markaya İlişkin Hedonik ve Rasyonel Algılamalarının Marka Değeri Boyutlarına Etkisi. Pazarlama ve Pazarlama Araștırmaları Dergisi. 8, 21-50.

Esch, F., Tobias, L., Bernd, H. S. ve Patrick, G. (2006). Are Brands Forever? How Brand Knowledge and Relationships Affect Current and Future Purchases. Journal of Product \& BrandManagement. 15 (2), 98-105.

Fedorikin, Alexander, C. Whan Park, and Matthew Thomson. (2008). "Beyond Fit and Attitude: The Effect of Emotional Attachment on Consumer Responses to Brand Extensions." Journal of Consumer Psychology 18 (4): 281-291. 
Fournier, S. (2009). Lessons Learned About Consumers' Relationships With Their Brands. Boston University School of Management. Çevrimiçi kaynak. http://questromapps.bu.edu/qstnet/ Personal/Faculty/Publication/pubUploads/WP2008-3.pdf. Erişim Tarihi: 16 Ocak 2018.

Gegez, E. (2015). Pazarlama Araştırmaları. İstanbul: Beta Yayınevi.

Gillespie, E. A. ve Noble, S. M. (2017). Stuck Like Glue: The Formation and Consequences of Brand Attachments Among Salespeople. Journal of Personal Selling \& Sales Management. 37 (3), 228-249.

Hirschman, E. C., ve Holbrook, M. B. (1982). Hedonic Consumption: Emerging Concepts, Methods and Propositions. Journal of Marketing. 46(3), 92-101.

Huang, Z., Zhang, C. ve Hu, J. (2017). Destination Brand Personality and Destination Brand Attachment - The Involvement of Selfcongruence. Journal of Travel \& Tourism Marketing. 34(9), 1198-1210.

Jawahar, P. D. ve R. Maheswari. (2009). Service Perception: Emotional Attachment As a Mediator of the Relationship Between Service Performance and Emotional Brand, The Icfai University. Journal of Marketing Management. 8(2), 7-22.

Jovanović, P., Vlastelica, T. ve Kostić, S. C. (2016). Impact of Advertising Appeals on Purchase Intention. Management. 81, 35-45.

Khan, U., Dhar, R. ve Wertenbroch, K. (2005). A Behavioral Decision Theory Perspective on Hedonic and Utilitarian Choice. S. Ratneshwar ve D. G. Mick (Ed.), Consumption: Consumer Motives, Goals, and Desires içinde. New York: Routledge, 2005, 144-165

Lu, J., Liu, Z. ve Fang, Z. (2016). Hedonic Products For You, Utilitarian Products For Me. Judgment and Decision Making. 11 (4), 332-341.

Mahmood, K., Hussain, M. ve F. Afzal. (2015). Moderating Role of Rational Thought Process in Measuring the Relationship Between Emotional Attachment and Branch Trust. Pakistan Journal of Commerce and Social Sciences. 9(25), 837-849.

Naresh, K. M. ve Birks, D. F. (2000). Marketing Research An Apllied Approach, Prentice Hall.

Odabaşı, Y. ve Barış, G. (2007). Tüketici Davranışı. İstanbul: MediaCat Yayınları.

O'curry, S. ve Strahilevitz M. (2001). Probability and Mode of Acquisition Effects on Choices Between Hedonic and Utilitarian Options. Marketing Letters. 12(1), 37-49.

Park. C. W. (2016). Brand Attachment: Theory and Practice. Advances in Consumer Research. 44, 3-6.

Park, C. W., MacInnis D. J., Priester, J., Eisingerich, A. B., ve Iacobucci, D. (2010), Brand Attachment and Brand Attitude Strength: Conceptual and Empirical Differentiation of Two Critical Brand Equity Drivers. Journal of Marketing. 74, 1-10.

Schifferstein, H. N. J. ve E. P. H. Zwartkruis-Pelgrim. (2008). Consumer-Product Attachment: Measurement and Design Implications. International Journal of Design. 2(3), 1-13.

Schmalz, S., ve Orth, U. R. (2012). Brand Attachment and Consumer Emotional Response to Unethical Firm Behavior. Psychology and Marketing, 29(11), 869-884. 
Swaminathan, V., Stilley, K., ve Ahluwalia, R. (2009). When Brand Personality Matters: The Moderating Role of Attachment Styles. Journal of Consumer Research. 35, 985-1002.

Thakur, A. ve Kaur, R. (2016). An Empirical Examination of Relationship Between Emotional Attachment and Attitudinal Brand Loyalty Towards Luxury Fashion Brands. DLSU Business \& Economics Review, 26(1), 70-80.

Thomson, M., MacInnis, D., J. ve C. W. Park. (2005). The Ties That Bind: Measuring the Strength of Consumers' Emotional Attachments to Brands. Journal of Consumer Psychology, 15 (1), 77-91.

Uztuğ, F. (2008). Markan Kadar Konuş. İstanbul: Mediacat Yayınları.

Voss, K. E., Spangenberg, E. R., ve Grohmann, B. (2003). Measuring the Hedonic and Utilitarian Dimensions of Consumer Attitude. Journal of Marketing Research, 40 (3), 310-320.

YouTube.com. (2015). IKEA Türkiye - Yatak Odası Reklam Filmi 2015. https://www.youtube. com/watch?v=Ca5jYoXKJX8 (Erişim Tarihi: 03.03.2018).

YouTube.com. (2016). IKEA - Evinizi Ezbere Değil Keyfinize Göre Döşeyin - Oturma. https:// www.youtube.com/watch?v=Ca5jYoXKJX8 (Erişim Tarihi: 03.03.2018).

YouTube.com. (2018). Reklam 3. https://www.youtube.com/watch?v=Ca5jYoXKJX8 (Erişim Tarihi: 03.03.2018).

\begin{tabular}{|l|l|}
\hline & $\begin{array}{l}\text { Prof. Dr. Nurhan BABÜR TOSUN - nurhantosun@marmara.edu.tr } \\
\text { Prof. Dr. Nurhan Zeynep TOSUN received her BA from College of Press in } \\
\text { 1983, MA in Radio and Television in 1985, and Ph.D in Public Relations in } \\
\text { 1991 from Marmara University. She is currently a faculty member in the Faculty } \\
\text { of Communication in Marmara University. She teaches brand management, } \\
\text { integrated marketing communication, global marketing strategies. She has } \\
\text { national and international publishings about advertising, brand management and } \\
\text { integrated marketing communication. }\end{array}$ \\
\hline $\begin{array}{l}\text { Mevlüt DÖNMEZ - mevlutdonmez@windowslive.com } \\
\text { Mevlüt Dönmez was born in 1984. He got bachelor degree from Selçuk } \\
\text { University, Public Relations and Publicity Department in 2011. He got master } \\
\text { degree from the same university and same department in 2015. He is a PhD } \\
\text { candidate in Marmara University and a research assistant in Süleyman Demirel } \\
\text { University. }\end{array}$ \\
\hline
\end{tabular}

